\title{
ENGAGEMENT IN GREEN PROCUREMENT: ANTECEDENTS AND OUTCOMES ON MANUFACTURING SMALL AND MEDIUM-SIZED ENTERPRISES FROM IRAN
}

\author{
Ramin Bashir Khodaparasti ${ }^{1^{*}}$, Hooshmand Bagheri Garabollagh ${ }^{2}$ \\ and Reza Mohammadpour ${ }^{3}$ \\ ${ }^{1)}$ Urmia University, Urmia, Iran. \\ ${ }^{2)}$ Semnan University, Semnan, Iran. \\ ${ }^{3)}$ University of Tehran, Tehran, Iran.
}

Please cite this article as:

Khodaparasti R. B., Garabollagh, H. B. and Mohammadpour, R., 2020. Engagement in Green Procurement: Antecedents and Outcomes on Manufacturing Small and Medium-Sized Enterprises from Iran. Amfiteatru Economic, 22(53), pp. 102-120.

DOI 10.24818/EA/2019/53/102

\begin{abstract}
Implementation of green procurement principles in the public and private sectors is an important issue in favour of sustainable development. This correlational survey aimed to identify and analyse the antecedents and outcomes of the adoption of product-based green procurement practices in manufacturing small- and medium-sized enterprises. Accordingly, the statistical population consisted of all manufacturing small- and medium-sized enterprises operating in West Azerbaijan Province, Iran, among which 120 samples was selected, using the complete enumeration sampling method. Managers of these manufacturing companies are more aware of the status of their respective company than anyone else; therefore, senior managers, middle managers, and supervisors were selected as the participants. The collected data was analysed using Smart-PLS software. Based on the findings, environmental concern, employee competency, motivation and rewards had significant positive effects on the adoption of product-based green procurement practices. However, there was no significant relationship between customer pressure and green procurement. The adoption of product-based green procurement practices also had a significant positive effect on corporate performance, market performance, social performance, and environmental performance. The findings and suggestions of the present study can provide marketers and managers with an insight to improve the performance of their respective manufacturing enterprise.
\end{abstract}

Keywords: product-based green procurement, green supply chain management, social performance, small and medium-sized enterprises.

JEL Classification: M11, Q01

* Corresponding author, Ramin Bashir Khodaparasti - anton_bucuresti@yahoo.com, r.bashirkhodaparast@urmia.ac.ir 


\section{Introduction}

Nowadays, green supply chain managers in small- and medium-sized manufacturing enterprises (SMEs) create environmental utility and satisfaction throughout their supply chains in order to improve their environmental performance, and thus, utilize green procurement (GP) as a strategic tool to gain sustainable competitive advantage (Ghosh, 2019). Procurement performance provides an important opportunity for integrating environmental aspects into all corporate processes and units, and helps managers reduce the environmental impacts of business measures (Preuss, 2005). In general, responsiveness to competitive, regulatory, and social pressures has been driven by environmental and financial performance. However, it seems that environmental commitment could be not only a means for complying with legal requirements, but also a source of competitive advantage for companies. Procurement progresses towards a green approach which include the potential for integrating environmental aspects into decision-making processes. Green procurement may also enable senior management to fulfil their environmental responsibilities across the whole supply chain (Guenther, Scheibe, and Greschner Farkavcová, 2010).

Due to a need to prevent global warming and climate change and to preserve natural resources, GP has attracted considerable attention in industry during the recent years. Therefore, industrial sectors should play an important role in reducing greenhouse gas emissions, which have had an adverse impact on the environment over the past decades. In fact, for most companies, environmental consciousness seems to be a business necessity, not just a choice. Moreover, the term "sustainability" has a comprehensive, naturalistic, and humanistic approach, and incorporates valuable concepts in the area of maintaining, promoting and improving the health of human beings and ecological systems in the long term, and meeting human needs without destroying the life of future generations.

In addition, achieving economic dynamicity, preserving living environment, and establishing social equality are major dimensions of sustainability (Linton, Klassen, and Jayaraman, 2007; Gimenez and Tachizawa, 2012). Procurement managers are increasingly focusing on product life-cycle assessments (LCAs). LCAs assess the impact of a product from farming to manufacturing, packaging, transportation, and ultimately the end of its useful life, with the aim of reducing its impact on the environment throughout its life (Heizer et al. 2017; Karna and Heiskanen, 1998). Procurement managers can significantly reduce the impact of products on the environment by selecting products that have the least impact on the environment. Green et al. (2012) argued that since companies are gradually moving towards better environmental practices across their supply chains, the traditional role of supply chain function is being re-evaluated. Carter and Carter (1998) argued that purchasing managers can replace eco-friendly materials, those that are less harmful to the health of human and the environment.

Despite the important role of purchasing functions in managing environmental issues, there is limited research in two key areas. First, researchers have argued that although there is a plethora of research on sustainability with different labels such as green supply chain management, sustainable supply chain, green innovation, and closed-loop supply chain, little attention has been paid to supply-side management of supply chains (Al-Ghwayeen and Abdallah, 2018; Mitra and Datta, 2014; Mohanty and Prakash, 2014; Hsu et al., 2013; Hoejmose, Brammer, and Millington, 2012; Chan et al., 2012). In their study, Blome, Hollos, and Paulraj (2014) stated that companies have recently been involved in GP that includes the 
upstream supply chain. Other scholars also observed that sustainability research in the field of supply management is dearth (Ageron, Gunasekaran, and Spalanzani, 2012).

Second, although the literature on the relationship between GP practices and company performance has been extensively reviewed, it is unclear what performance is exactly related to the adoption of GP practices (Chan et al., 2012; Carter, Kale, and Grimm, 2000). Previous studies only focused on one variable such as corporate performance, business performance, or variables of environmental and economic performance (Chan et al., 2012; Lee, Tae Kim, and Choi, 2012; Zhu and Sarkis, 2004; Zhu, Sarkis, and Geng, 2005; Zailani et al., 2012; Green et al., 2012). The present study is one of the few experimental studies conducted in developing countries in order to strengthen and validate previous findings on the antecedents and outcomes of the adoption of GP initiatives in manufacturing SMEs. In addition, some scholars believe that the repetition of previous studies in different environments by using different datasets raises the value of research in operations management (Singhal et al., 2008).

On the other hand, due to the limited literature on GP in developing or underdeveloped countries (Ghosh, 2019), the present research aimed to comprehensively investigate the effects of employee competency, employee motivation and rewards, customer pressure and environmental concern on the adoption of product-based GP in manufacturing SMEs in Iran. It also attempted to explain the relationships between variables of market performance, corporate performance, social performance, and environmental performance. Variables of employee competency, motivation and rewards, and socio-environmental performance have not been addressed by the previous studies on supply chain and GP improvement in manufacturing SMEs. Hence, these variables are the core elements of the present research which indicates its innovative aspect. In addition, supply chain management scholars have recently paid much attention to the important discussion of green procurement. Nowadays, various companies, the people at large, and especially environmentalists pay more attention to the integration of this concept into the design of green supply chain networks.

Therefore, the following two research questions were formulated to achieve the purposes of the present study:

a) In a developing country like Iran, what factors may affect the adoption of product-based GP practices in manufacturing SMEs?

b) What is the relationship between the degree of the adoption of product-based GP practices by managers and different dimensions of performance?

In the next section, the theoretical framework and related literature of the issue have been reviewed. Section (3) explains the research methodology. Empirical analysis has been presented in fourth section. Final section concludes the paper.

\section{Theoretical framework and literature review}

\subsection{Green procurement (GP)}

Purchasing or procurement is a process with which companies obtain their goods and services, raw materials, elements, and other resources needed to execute their operations (Ghosh, 2019). Over the years, due to the growth strategy, purchasing performance has 
mainly focused on core activities (Appolloni et al., 2014), and has had an increasing impact on the natural environment. Traditional purchasing focuses primarily on three criteria including cost, quality and delivery. In addition, GP is known as environmental purchasing. Besides these three traditional criteria, GP also considers environmental issues related to supply management decisions (Yook, Choi, and Suresh, 2018; Zailani et al., 2012). Green purchasing is defined as an environmentally-conscious purchasing that reduces waste sources and improves recycling process (Min and Galle, 2001). Besides, Large and Thomsen (2011) defined green or environmental purchasing as the integration of environmental considerations into purchasing policies, plans and measures. In effect, although environmental purchasing, that is green procurement, is a subset of environmental supply chain management, depends on a company's structure and the importance of the purchasing function, it can be a very large subset (Zsidisin and Siferd, 2001).

There is extensive literature on various aspects of green management in the past decade; however, more areas still need to be explored in the future. Among relevant review papers, few studies were found to review part of the literature on GP. In their study, Seuring and Müller (2008) provided a literature review on sustainable supply chain management based on 191 papers and presented a conceptual framework, where green purchasing was only a small part of their review. In addition, Sarkis, Zhu, and Lai (2011) presented the concept of sustainability in supply chain management, and considered environmental, social and economic performance as major aspects of GP; however, in the same vein, procurement was a small part of their review. Several researchers examined the positive effect of green and environmental purchasing as a possible tool that reduces waste sources and improves recycling, and favors other environmental benefits as well (Carter and Carter, 1998; Min and Galle, 2001; Guenther, Scheibe, and Greschner Farkavcová, 2010).

\subsection{Antecedents of adopting product-based GP practices}

Bamberg (2003) considered the concept of environmental concern as a general attitude that depends on cognitive and emotional assessments of customers in terms of environmental protection. Therefore, it can be said that environmental concern has been developed following the assessment of the attitude and behavior of individuals in response to environmental impacts (Ajzen, 2002). Manufacturing SMEs can gain competitive advantage over other competing companies, generate more profits, and improve their corporate and market performance by changing the attitude of individuals towards environmental issues and producing green and eco-friendly products (Rizwan, Ahmad, and Haq, 2014).

Moreover, the impact of various activities involved in supply chain processes on social life and environmental issues related to sustainable development should be taken into account. Therefore, due to the importance of social and environmental concerns, as well as economic factors, the concepts of green supply chain management and GP have emerged in supply chain planning. On the other hand, in supply chains, corporate competencies are accompanied with superiority in operational and business performance (Huo et al., 2014). This implies that managers can achieve sustainable GP and an outstanding competence if they enhance their supply chain management infrastructures.

Considering the transient condition of global markets and competition of supply chains in recent years, companies have found that they need to maximize their efforts to create and 
maintain sustainable competitive advantage and GP in order to grow and survive in today's turbulent environment. On the other hand, customers' and stakeholders' pressures have forced companies to pay more attention to the components of sustainable development (e.g. social and environmental issues), and this has led to the emergence of the concept of sustainable GP management. Customer pressure is an important determinant of whether companies have an environmental plan or not. The change in customer behavior towards being 'responsible' has attracted the attention of companies and managers, and has urged them to develop responsible practices (Klassen and Vachon, 2003). The literature does not provide definitive results regarding the role of customer pressure in developing GP; however, many researchers have considered customer needs as an important motivator for sustainable procurement management (Deephouse and Heugens, 2009). Increasing customer awareness of social behavior is not limited to assessing a company's manufacturing activities, but it extends to its indirect effects and impacts on society. For example, customers can react to negative environmental and social impacts created by a company's supply chain, through increasing pressure on that company.

Empirical evidence has proven the relationship between customer pressure and both internal and external environmental activities (Gualandris and Kalchschmidt, 2014). Employee reward and recognition system can effectively motivate staff. In a manufacturing SME, employees must know what actions, practices, or factors will help them get rewards. However, these factors must be consistent with organizational goals (Mokhtar et al., 2019). In addition, managers must master the art of motivating staff, an art that leads to sustainable GP and productivity.

Blome et al. (2014) stated that market performance has a significant positive impact on green procurement. Besides, the importance of financial performance in promoting green procurement was not convincing. This implies that market performance enhances corporate vision, thereby putting more emphasis on companies to pursue green procurement initiative. On the other hand, Dal Maso et al. (2018) studied financial performance as a moderating role and concluded that good financial performance has positive effects on the environmental performance of manufacturing companies. AlNuaimi and Khan (2019) examined the relationship between organizational innovation capability and green procurement performance with the mediating role of employee commitment to change. The results of their research showed that innovativeness of organization has a positive effect on green procurement implementation. Moreover, employees' commitment to change affects the implementation of green procurement.

\subsection{Outcomes of adopting product-based GP practices}

Corporate social responsibility is a set of activities carried out to achieve some social goals that are beyond financial goals. Companies must voluntarily integrate economic, social, civil, and environmental issues into their activities and their relationships with employees, customers, suppliers, local authorities, NGOs, the environment, etc. In other words, the concept of corporate social responsibility is a comprehensive and multidimensional idea of performance, not simply an economic and financial issue (Hirigoyen and Poulain-Rehm, 2014). Environmental performance is among the most important social responsibilities of a company (Wang et al., 2016). It includes a set of eco-friendly operations carried out by a company. Many companies are looking for ways to understand, recognize, and improve their environmental performance. This can be realized by effective management of those 
activities, goods and services that have a significant impact on the environment (Medarevic, 2012). Corporate performance is the degree to which a company is superior to its competitors (Rai, Patnayakuni, and Seth, 2006). Corporate performance has always been a critical issue in financial literature, as well as among business executives in all types of companies, because it implies the survival of a company. High performance reflects the effectiveness and efficiency of management in using corporate resources, which, in turn, contribute to the development of national economy (Almajali, Alamro, and Al-Soub, 2012).

Closs, Speier, and Meacham (2011) conducted a study on supply chain and GP to investigate the role of sustainable supply chain in improving environmental and social performance of companies. They concluded that the studied companies could improve their environmental and social performance and gain competitive advantage by establishing sustainable supply chain management. Esfahbodi, Zhang, and Watson (2016) conducted a similar study on some Iranian and Chinese companies. The results showed that the adoption of sustainable supply chain management in both Iran and China improved environmental performance. A higher performance was observed in Chinese markets; however, it did not necessarily lead to improved cost performance. They also showed that companies should adopt sustainable supply chain management practices widely at their lowest financial levels in order to better improve their corporate and environmental performance. Hence, managers can improve corporate performance by adopting appropriate policies. Market performance is defined as the effectiveness of a company's marketing activities and is measured by factors such as level of customer satisfaction, customer value, customer retention, and desired market share attainment (Homburg and Pflesser, 2000).

Treacy and Wiersema (1993), in their study on the effect of supply chain management capabilities on business performance of various industries in the U.S., investigated direct and indirect effects of outside-in, inside-out, and spanning capabilities on perceived customer value, customer loyalty, market performance, and corporate performance. Based on the results of their study, the effects of spanning capability on perceived customer value and customer loyalty were stronger than the effects on market and corporate performance. In this regard, the study of Agbesi, Fugar, and Adjei-Kumi (2018) was very important, because it investigated the effects of competitive pressure, stakeholder pressure, organizational values, environmental support, top management support, and technology on sustainable procurement within the context of public organizations. However, the present study addressed different antecedents and outcomes (customer pressure, employee competency, environmental concern, adoption of product-based GP practices, environmental performance, and market performance). Other studies have examined internal and external factors (firm size, suppliers' performance, customer competitiveness, and internal environment) of GP in the business industry, among which the study of Appolloni et al. (2014) is the most comprehensive one.

In fact, supplier performance can be enhanced through properly designed environmental standards, which can not only drive innovation, but also reduce overall costs and higher product value as well as bio-performance. Doing green procurement activities will enhance the performance of companies in economic, environmental and operational aspects. Therefore, manufacturing companies can integrate green procurement activities with environmental requirements in the process of product design, selection and supply of raw materials, production and manufacturing, distribution and transportation processes, etc. (Mani et al., 2018). In other words, companies and suppliers strive to minimize adverse 
environmental impacts on logistic activities through recycling, reuse, re-packaging, waste removal, etc. effectively in order to reduce the pollution which will adversely improve company performance (Seman et al., 2018).

The following research hypotheses were proposed with regard to the above statements:

H1: Environmental concern has a significant effect on the adoption of product-based GP practices.

H2: Employee competency has a significant effect on the adoption of product-based GP practices.

H3: Customer pressure has a significant effect on the adoption of product-based GP practices by managers.

H4: Employee motivation and rewards have significant effects on the adoption of productbased GP practices.

H5: Adoption of product-based GP practices has a significant effect on market performance.

H6: Adoption of product-based GP practices has a significant effect on social performance.

H7: Adoption of product-based GP practices has a significant effect on environmental performance.

H8: Adoption of product-based GP practices has a significant effect on corporate performance.

\subsection{Conceptual research model}

With regard to the above hypotheses, the respective research model is presented in Figure (no.1).

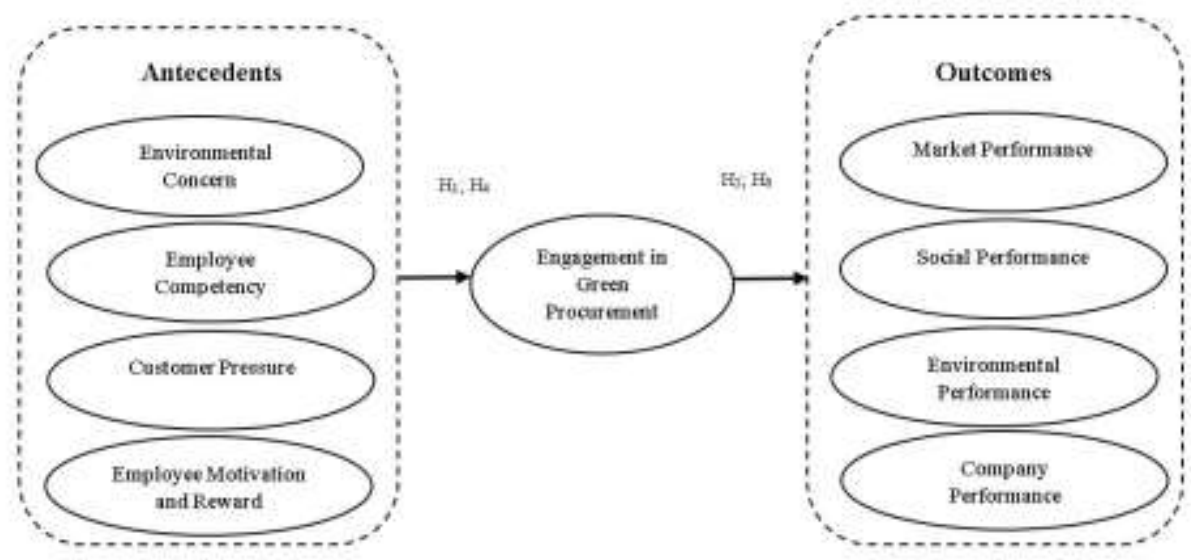

Figure no. 1: Conceptual research model

Source: Research findings 


\section{Methods}

This study is a descriptive cross-sectional survey. With regard to the measurement methods used in this study, the accuracy required for data collection, duration of research, relevant costs, and other factors, the questionnaire was used to collect the data. The questionnaire consisted of 30 items in nine areas of environmental concern (3 items), customer pressure (3 items), employee competency (3 items), employee motivation and rewards (3 items), adoption of product-based GP practices (6 items), market performance ( 2 items), social performance ( 3 items), environmental performance ( 4 items), and corporate performance (3 items). The items were scored on a five-point Likert scale. The research tool was a standardized questionnaire derived from valid sources; however, to ensure the consistency of the items with the actual environment of manufacturing SMEs, the questionnaire was distributed among several management professors to express their opinions on different items, and necessary corrective measures were taken. The statistical society consisted of all manufacturing SMEs operating in West Azerbaijan Province, Iran, of which we selected as the sample $(n=120)$ using the complete enumeration sampling method. Managers are more aware of the status of their respective company than anyone else; therefore, senior managers, middle managers, and supervisors were selected as the participants.

To ensure the reliability of the measurement tool, Cronbach's alpha coefficient was calculated (Table no. 3). In addition, the reliability and validity of the measurement tool were calculated using the softwares of SPSS and Smart-PLS. Table no. 1 presents the demographic characteristics of the participants.

Table no. 1: Description of the Demographic Characteristics of the Sample

\begin{tabular}{|c|c|c|c|}
\hline \multicolumn{2}{|c|}{ Demographic Features } & Abundance & Frequency (\%) \\
\hline \multirow{2}{*}{ Gender } & Male & 102 & 85 \\
\hline & Female & 18 & 15 \\
\hline \multirow{3}{*}{ Respondents Profile } & Senior Manager & 55 & 46 \\
\hline & Middle Managers & 55 & 46 \\
\hline & Supervisors & 10 & 8 \\
\hline \multirow{4}{*}{ Number of Employees } & $50-100$ & 46 & 38 \\
\hline & $100-200$ & 42 & 35 \\
\hline & $200-300$ & 23 & 19 \\
\hline & $>300$ & 9 & 8 \\
\hline \multirow{5}{*}{ Education } & High School Diploma & 21 & 17.5 \\
\hline & Associate Degree & 12 & 10 \\
\hline & Bachelor's Degree & 59 & 49.2 \\
\hline & Master's Degree & 19 & 15.8 \\
\hline & Doctoral Degree & 9 & 7.5 \\
\hline \multirow{4}{*}{$\begin{array}{c}\text { Management Experience } \\
\text { (year) }\end{array}$} & $1-5$ & 40 & 34 \\
\hline & $6-10$ & 35 & 29 \\
\hline & $11-15$ & 30 & 25 \\
\hline & $>15$ & 15 & 12 \\
\hline
\end{tabular}

Source: Research findings 
A total of $85 \%$ of the participants were male and $15 \%$ were female. In addition, 21 had a high school diplomas, 12 an Associate degree, 59 a Bachelor's degree, 19 a Master's degree, and 9 a Doctoral degree.

Studied companies are all located in West Azerbaijan Province, Iran. They are listed by type of the industry in Table (no. 2).

Table no. 2: Studied Companies Category

\begin{tabular}{|l|c|}
\hline \multicolumn{1}{|c|}{ Activity Area } & Sample Number (Total: 120) \\
\hline dairy products and pizza cheese & 5 \\
\hline industrial breads & 4 \\
\hline printing and packaging & 8 \\
\hline rubber parts & 11 \\
\hline dairy products & 12 \\
\hline packaging for beans and nuts & 9 \\
\hline PVC door and window & 4 \\
\hline sugar production and sugar packaging & 6 \\
\hline turning Services & 4 \\
\hline conserved and canned food stuff & 9 \\
\hline plastic fruit box & 12 \\
\hline wood furniture & 8 \\
\hline bread and pastry machineries & 9 \\
\hline chicken nest shell & 5 \\
\hline colored roof sheets & 8 \\
\hline agricultural and livestock machineries & 6 \\
\hline
\end{tabular}

Source: Research findings

Two indicators of reliability and discriminant validity were used to test the goodnessof-fit of the research model. As shown in Table (no. 3), reliability is measured by calculating factor loadings, Cronbach's alpha coefficients, composite reliability, and average variance extracted (AVE), and their acceptable values were 0.7, 0.7, 0.7, and 0.5, respectively (Hair et al., 2011). As shown in Table no. 3, all values obtained for the latent variables are acceptable; therefore, the reliability and convergent validity of the research constructs are confirmed. It can be seen from Table no. 3 that all factor loadings at this level of confidence are significant (factor loadings of all variables are higher than the acceptable level of 0.4). This means that the correlation coefficients of the explicit variables have the capability to estimate their own hidden variables and thus indicate that the validity of the model construct is acceptable.

In addition, variance inflation factor (VIF) was used to detect collinearity. This factor measures the severity of multicollinearity in an ordinary least squares regression analysis. In fact, it indicates how much the variance of an estimated coefficient is increased because of collinearity. As an empirical rule, values greater than 2 indicate higher levels of collinearity. In other words, the higher the value of this factor is, the greater the variance of the coefficients will be, and thus, the regression model will be less suitable for prediction. 
Table no. 3: Constructs and measuring items

\begin{tabular}{|c|c|c|c|c|c|}
\hline Items & $\begin{array}{c}\text { Factor } \\
\text { loadings }\end{array}$ & AVE & $\begin{array}{l}\text { Composite } \\
\text { Reliability }\end{array}$ & $\begin{array}{c}\text { Cronbach's } \\
\text { Alpha }\end{array}$ & VIF \\
\hline $\begin{array}{c}\text { Environmental Concern (Ghosh, 2019) } \\
\end{array}$ & & 0.726 & 0.888 & 0.825 & - \\
\hline $\begin{array}{l}\text { Developing an environmental management system in our firm has helped } \\
\text { us to become environmentally responsible. }\end{array}$ & 0.860 & & & & 1.504 \\
\hline $\begin{array}{l}\text { Developing a waste reduction plan has helped us to become } \\
\text { environmentally responsible. }\end{array}$ & 0.815 & & & & 1.503 \\
\hline $\begin{array}{l}\text { Developing a formal policy on green logistics has been a key step in our } \\
\text { firm to become socially responsible. }\end{array}$ & 0.881 & & & & 1.004 \\
\hline Employee Competency (Safavi and Bouzari, 2019) & & 0.550 & 0.708 & 0.775 & - \\
\hline I am able to explore my possibilities on the labor market. & 0.748 & & & & 2.093 \\
\hline I know how to search for developments in my area of work. & 0.798 & & & & 1.911 \\
\hline I can create a layout for what I want to achieve in my career. & 0.756 & & & & 1.635 \\
\hline Customer Pressure (Ghosh, 2019) & & 0.719 & 0.884 & 0.812 & \\
\hline $\begin{array}{l}\text { We periodically participate in environment-related educational workshops } \\
\text { organized by our customers. }\end{array}$ & 0.767 & & & & 2.242 \\
\hline $\begin{array}{l}\text { Number of environment friendly products in our product line has shown } \\
\text { increasing trend over the years due to customer requirements. }\end{array}$ & 0.854 & & & & 1.911 \\
\hline $\begin{array}{l}\text { Number of customers seeking environment friendly products from us has } \\
\text { been increasing over the last } 2 \text { years. }\end{array}$ & 0.915 & & & & 2.273 \\
\hline Employee Motivation and Reward (Güngör, 2011) & & 0.804 & 0.925 & 0.875 & - \\
\hline Financial rewards (salary, bonus and perquisite) increase the motivation. & 0.874 & & & & 2.055 \\
\hline Price increase of salaries raises the performance of the employees up. & 0.912 & & & & 2.757 \\
\hline Working period affects motivation. & 0.903 & & & & 2.740 \\
\hline $\begin{array}{l}\text { Engagement in Product-Based in Green Procurement (Solovida } \\
\text { and Latan, 2017) }\end{array}$ & & 0.572 & 0.841 & 0.776 & - \\
\hline $\begin{array}{l}\text { Cooperating with each other to enhance the utilization efficiency of raw } \\
\text { materials }\end{array}$ & 0.842 & & & & 1.503 \\
\hline Participating in partners' production processes & 0.767 & & & & 2.093 \\
\hline Green management of companies' products & 0.873 & & & & 1.755 \\
\hline Green handling of wastes (waste liquid, gas, etc.) & 0.833 & & & & 1.866 \\
\hline Suppliers' packaging materials are green. & 0.768 & & & & 1.742 \\
\hline The whole process control of products & 0.805 & & & & 1.758 \\
\hline Market Performance (Psomas, Kafetzopoulos, and Gotzamani, & & 0.713 & 0.831 & 0.722 & - \\
\hline The company's market share is high. & 0.910 & & & & 1.256 \\
\hline The company's image within the market is high. & 0.837 & & & & 0.989 \\
\hline Social Performance (Perera and Hewege, 2016) & & 0.619 & 0.829 & 0.718 & - \\
\hline $\begin{array}{l}\text { I try to avoid buying products from companies with a poor reputation for } \\
\text { social responsibility. }\end{array}$ & 0.811 & & & & 1.502 \\
\hline It makes me angry when companies are socially irresponsible. & 0.835 & & & & 1.632 \\
\hline $\begin{array}{l}\text { I am willing to boycott companies that I do not consider to be socially } \\
\text { responsible. }\end{array}$ & 0.708 & & & & 1.201 \\
\hline Environmental Performance (Solovida and Latan, 2017) & & 0.703 & 0.904 & 0.860 & - \\
\hline Compliance with the requirements or expectations of standard & 0.863 & & & & 2.040 \\
\hline Implementation of environmental policies and programs & 0.884 & & & & 2.626 \\
\hline Relationship with the community & 0.749 & & & & 2.420 \\
\hline The solid waste output & 0.752 & & & & 1.717 \\
\hline Company Performance (Huo, 2012) & & 0.585 & 0.804 & 0.719 & - \\
\hline Our company can quickly introduce new products into the markets. & 0.763 & & & & 1.648 \\
\hline Our company can quickly respond to changes in market demand. & 0.829 & & & & 1.032 \\
\hline Our major supplier can quickly introduce new products into the markets. & 0.867 & & & & 1.867 \\
\hline
\end{tabular}

Source: Research findings 


\subsection{Discriminant Validity}

In this method, only first-order latent variables were entered into the matrix. Table no. 4 presents relevant results.

Table no. 4: Discriminant Validity (Fornell and Larcker, 1981)

\begin{tabular}{|c|c|c|c|c|c|c|c|c|c|}
\hline- & 1 & 2 & 3 & 4 & 5 & 6 & 7 & 8 & 9 \\
\hline $\begin{array}{l}\text { 1. Company } \\
\text { Performance }\end{array}$ & 0.764 & - & & & & & & & \\
\hline 2. Customer Pressure & 0.614 & 0.847 & & & & & & & \\
\hline $\begin{array}{l}\text { 3. Employee } \\
\text { Competency }\end{array}$ & 0.394 & 0.675 & 0.741 & & & & & & \\
\hline $\begin{array}{l}\text { 4. Employee Motivation } \\
\text { and Reward }\end{array}$ & 0.325 & 0.355 & 0.433 & 0.896 & & & & & \\
\hline $\begin{array}{l}\text { 5. Engagement in } \\
\text { Product-Based GP }\end{array}$ & 0.404 & 0.258 & 0.598 & 0.659 & 0.756 & & & & \\
\hline $\begin{array}{l}\text { 6. Environmental } \\
\text { Performance }\end{array}$ & 0.616 & 0.377 & 0.485 & 0.332 & 0.417 & 0.838 & & & \\
\hline 7. Market Performance & 0.546 & 0.283 & 0.429 & 0.430 & 0.616 & 0.497 & 0.844 & & \\
\hline 8. Social Performance & 0.557 & 0.361 & 0.279 & 0.265 & 0.370 & 0.383 & 0.413 & 0.786 & \\
\hline $\begin{array}{l}\text { 9. Environmental } \\
\text { Concern }\end{array}$ & 0.257 & 0.221 & 0.397 & 0.586 & 0.283 & 0.452 & 0.444 & 0.377 & 0.852 \\
\hline
\end{tabular}

Source: Research findings

In each latent variable, the square root of each AVE along the diagonal was greater than its correlation with the lower left off-diagonal elements. Therefore, it can be stated that the research constructs (i.e. latent variables) had greater correlations with their indices than with other constructs. In other words, the discriminant validity of the model was acceptable (Fornell and Larcker, 1981).

\section{Findings}

\subsection{Goodness-of-fit of the research model}

The indices obtained in PLS all show good quality. That is, these indices are numeric between 1 and 0 , and the closer they are to 1 than 0.5 , the greater the fitness will be. The general criterion for the partial least squares method is called GOF. The fitness results are presented in Table no. 5 .

Table no. 5: Goodness-of-fit indices

\begin{tabular}{|c|c|c|c|c|}
\hline Index type & Absolute index & Relative index & Outer model index & Inner model index \\
\hline Model index & 0.689 & 0.795 & 0.783 & 0.803 \\
\hline \multicolumn{5}{|c}{ Source: Research findings }
\end{tabular}

In this study, the relative index was higher than the absolute index. The goodness-of-fit index value depends on the inner model index rather than on the outer model index. According to Table no. 5, the inner model index is 0.803 , so it can be concluded that the model studied favors a high fitness. 
Path analysis was used to test the research hypotheses. Significance values were used to test the null hypotheses. To reject a hypothesis, the value must be less than +1.96 . Table no. 6 and Figure no. 2 show the structural equation modeling in the standardized and significant coefficient states.

Table no. 6: Statistical Results of the Structural Model

\begin{tabular}{|c|c|c|c|c|c|c|c|c|}
\hline \multicolumn{3}{|c|}{ Hypothesized paths } & \multirow{2}{*}{\begin{tabular}{|c|}
$\boldsymbol{\beta}$ \\
$0.185^{* *}$
\end{tabular}} & \multirow{2}{*}{$\begin{array}{c}\begin{array}{c}\text { T- } \\
\text { value }\end{array} \\
2.405\end{array}$} & \multirow{2}{*}{$\begin{array}{r}\mathbf{R}^{\mathbf{2}} \\
-\end{array}$} & \multirow{2}{*}{$\begin{array}{c}\text { Adj. } \\
\mathbf{R}^{2} \\
- \\
-\end{array}$} & \multirow{2}{*}{$\begin{array}{l}\mathbf{Q}^{2} \\
-\end{array}$} & \multirow{2}{*}{\begin{tabular}{|c|} 
Result \\
Supported
\end{tabular}} \\
\hline Environmental Concern & $\rightarrow$ & \begin{tabular}{|c|} 
Engagement in Product- \\
Based Green \\
Procurement
\end{tabular} & & & & & & \\
\hline Employee Competency & 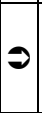 & \begin{tabular}{|c|} 
Engagement in Product- \\
Based Green \\
Procurement
\end{tabular} & $0.299 * *$ & 3.308 & - & - & - & Supported \\
\hline Customer Pressure & 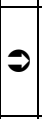 & \begin{tabular}{|c|} 
Engagement in Product- \\
Based Green \\
Procurement \\
\end{tabular} & $0.091 * *$ & 2.152 & - & - & - & Supported \\
\hline $\begin{array}{l}\text { Employee Motivation } \\
\text { and Rewards }\end{array}$ & $\Rightarrow$ & \begin{tabular}{|c|} 
Engagement in Product- \\
Based Green \\
Procurement \\
\end{tabular} & $0.398 * * *$ & 3.715 & 0.576 & 0.556 & 0.254 & Supported \\
\hline $\begin{array}{c}\text { Engagement in Product- } \\
\text { Based Green } \\
\text { Procurement }\end{array}$ & $\boldsymbol{\theta}$ & Market Performance & $0.616 * * *$ & 10.657 & 0.380 & 0.373 & 0.234 & Supported \\
\hline $\begin{array}{c}\text { Engagement in Product- } \\
\text { Based Green } \\
\text { Procurement } \\
\end{array}$ & के & Social Performance & $0.370 * * *$ & 3.414 & 0.137 & 0.127 & 0.065 & Supported \\
\hline $\begin{array}{c}\text { Engagement in Product- } \\
\text { Based Green } \\
\text { Procurement } \\
\end{array}$ & 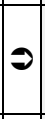 & $\begin{array}{l}\text { Environmental } \\
\text { Performance }\end{array}$ & $0.417 * * *$ & 4.748 & 0.174 & 0.165 & 0.108 & Supported \\
\hline $\begin{array}{c}\text { Engagement in Product- } \\
\text { Based Green } \\
\text { Procurement } \\
\end{array}$ & 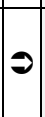 & Company Performance & $0.404 * * *$ & 3.977 & 0.163 & 0.154 & 0.075 & Supported \\
\hline
\end{tabular}

Note: Symbols of $* *$ and $* * *$ indicate being significant at $5 \%$ and $1 \%$ levels, respectively. Source: Research findings

Table no. 6 shows the estimated coefficients for the developed relations and their significance values. According to the test results, the first hypothesis was supported with a path coefficient of 0.185 , and at a significance level of $0.05 \quad(\mathrm{p}<0.05)$; therefore, environmental concern has a significant positive effect on the adoption of product-based GP practices. It was also found that employee competency has a significant positive effect on the adoption of product-based GP practices (path coefficient $=0.299 ; p<0.01$ ); thus, the second hypothesis was also supported. In addition, the third hypothesis was supported (path coefficient $=0.091 ; \mathrm{p}<0.05)$; therefore, customer pressure has a significant positive effect on the adoption of product-based GP practices. The fourth hypothesis was also supported (path coefficient $=0.398 ; \mathrm{p}<0.01$ ), which implies that employee motivation and rewards have significant positive effects on the adoption of product-based GP practices.Finally, the fifth, sixth, seventh, and eighth hypotheses were supported with path coefficients of 0.616 , $0.370,0.417$, and 0.404 , respectively, and at a significance level of 0.01 , indicating that the adoption of product-based GP practices has significant effects on market, social, environmental and corporate performance. Coefficient of determination $\left(\mathrm{R}^{2}\right)$ and predictive 
relevance $\left(\mathrm{Q}^{2}\right)$ used to test the goodness-of-fit of the research model for the endogenous research variable are presented in Table no. 6 . The high $\mathrm{R}^{2}$ value obtained for the variable of 'adoption of product-based GP practices' indicates that the structural model fitted the data well. Regarding the predictive power of the model, $\mathrm{Q}^{2}$ value obtained for the endogenous variable is greater than 0.15 , so it can be concluded that the model has a good predictive power (Henseler et al., 2009).

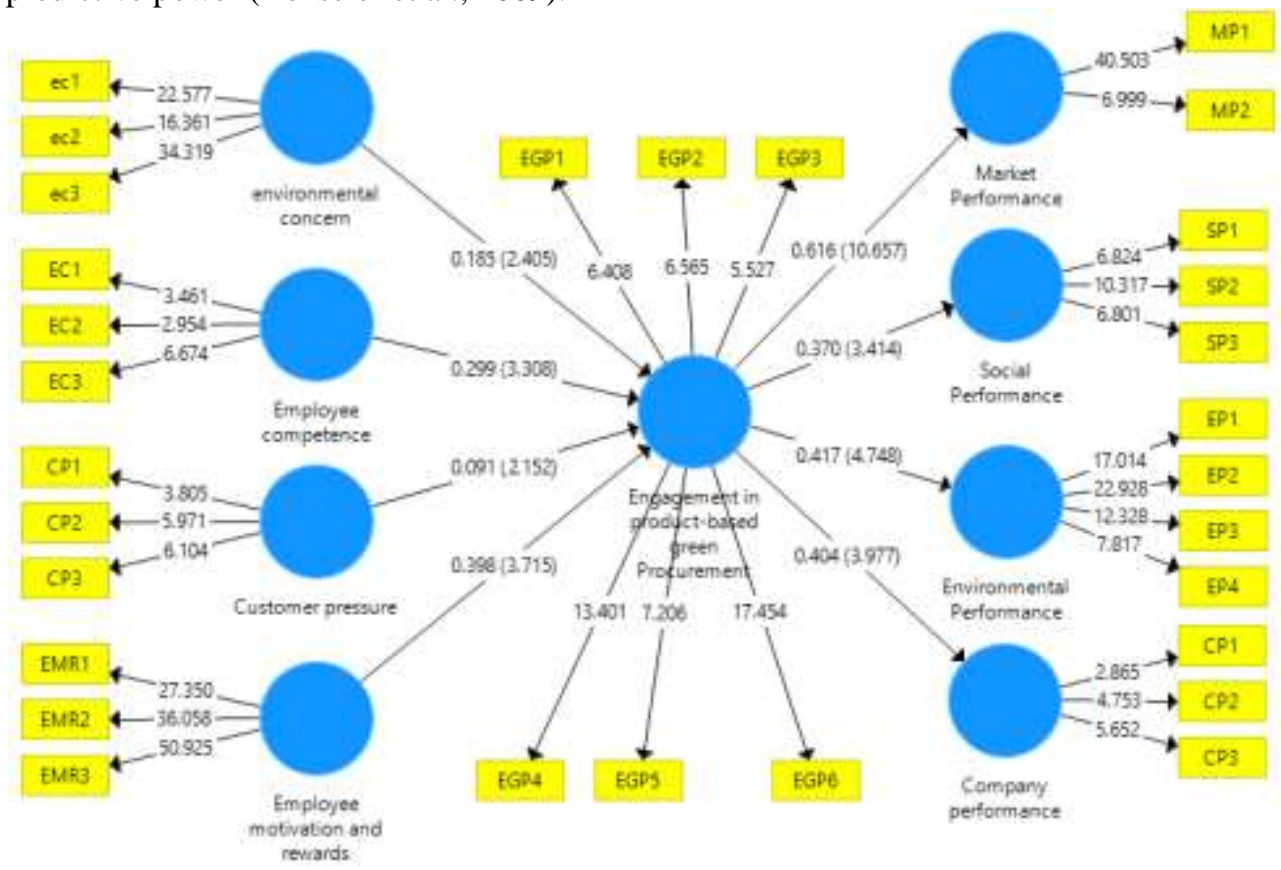

Figure no. 2: Structural equation modeling Source: Research findings

\section{Conclusion and suggestions}

Green procurement and sustainable competitive advantage are key issues for companies in today's competitive environment. Some of these major concerns of today's managers include gaining the satisfaction of current customers, retaining them, and improving market performance. Accordingly, studying the adoption of product-based GP practices and the relevant influential factors can substantially help these managers. Regarding the impact of environmental concern on the adoption of product-based GP practices, this study suggestes that GP integrates environmental concerns into the concept of supply chain through improving collaboration and coordination among supply chain members.

In addition, this study suggests that in today's competitive world, various companies and manufacturers need to pay more attention to the environment and the issue of GP. This is due to the large number of suppliers and their intensive competition, on one hand, and high consumer expectations for providing quality products, and paying more attention to the environment, on the other. 
The results of the research furthermore indicates the significant positive effects of the variables of employee competency, employee motivation and rewards on the adoption of product-based GP practices. This implies that in sustainable supply chains, companies gain competencies that can lead to superiority in operational and business performance. In other words, a company's operational division is a crucial part of supply chains where great opportunities can be provided, and outstanding employee and corporate superiorities and competencies can be identified in this division through maintaining the integrity of an entire supply chain. Customer pressure, as the survey result indicates, has a significant positive effect on the adoption of product-based GP practices. This is consistent with the results of the study of Gualandris and Kalchschmidt (2014). This finding confirms the enormous impact of customer pressure on companies in pushing them towards undertaking sustainable supply chain management activities.

Companies are suggested to realize that receiving appropriate timely feedbacks from customers on environmental and social impacts of corporate activities accelerates the better establishment of sustainable process management. Hence, companies that better prepare themselves for understanding and meeting customers' needs can readily develop internal supply chain activities. On the other hand, companies are also suggested to progress towards sustainable GP activities and objectives by paying more attention to the views of customers and receiving and monitoring their feedbacks on various effects of the supply chain (that the company is part of it) and through considering these views in their relationships with suppliers (in cases such as establishment of health, safety, and environmental management systems, and compliance with green purchasing and design requirements). In addition, considering the significant positive effect of customer pressure on GP, managers of manufacturinf companies are suggested to create a customer relationship management system for understanding and receiving customer demands in order to meet their social demands at the right time.

Based on the results of the study, it is conclded that the adoption of product-based GP practices has significant effects on environmental, market, social, and corporate performance. This indicates that GP practices improve environmental performance of manufacturing SMEs. As a matter of fact, sustainable supply chain practices in these companies reduce the production of harmful environmental factors and pollutants. A significant relationship was also found between GP and corporate performance. This implies that these components (GP and sustainable supply chain) can help manufacturing SMEs improve their performance. Since sustainable GP practices can help companies improve their environmental, market, and corporate performance, manufacturing SMEs are recommended to replace their traditional supply chain systems with a sustainable supply chain system.

Developing countries, like Iran, are also suggested to develop suitable infrastructures in order to establish sustainable supply chain systems in manufacturing SMEs; this will contribute to the preservation of natural and biological resources. The establishment of a sustainable supply chain system in manufacturing SMEs increases employee motivation and productivity and reversely reduces absenteeism (due to lower labor costs and better job conditions); hence, all companies are recommended to adopt sustainable GP practices. Considering the positive effects of the adoption of product-based GP practices on corporate, environmental, and market performance, managers of the manufacturing SMEs are recommended to pave the path for the establishment of sustainability, and motivate all 
members of the supply chain in order to receive the financial and environmental benefits of this process.

This study justifies Li et al. (2006)'s findings that the implementation of sustainable GP management can directly boost market and financial performance of companies in the long run. In other words, manufacturing companies can improve their financial and market performance through promoting their production and packaging operations. Satisfactory social performance can benefit not only a company but also people adjacent the company.

In a word, managers of manufacturing companies specially in developing countries must consider factors affecting the adoption of product-based GP practices.

\section{References}

Agbesi, K., Fugar, F. D., and Adjei-Kumi, T. (2018). Modelling the adoption of sustainable procurement in construction organisations. Built Environment Project and Asset Management, 8(5), pp. 461-476.

Ageron, B., Gunasekaran, A., and Spalanzani, A. (2012). Sustainable supply management: An empirical study. International Journal of Production Economics, 140(1), pp. 168-182.

Ajzen, I. 2002. Perceived behavioral control, self-efficacy, locus of control, and the theory of planned behavior. Journal of Applied Social Psychology, 32(4), pp. 665-683.

Al-Ghwayeen, W. S., and Abdallah, A. B. (2018). Green supply chain management and export performance: The mediating role of environmental performance. Journal of Manufacturing Technology Management, 29(7), pp. 1233-1252.

Almajali, A. Y., Alamro, S. A., and Al-Soub, Y. Z. (2012). Factors affecting the financial performance of Jordanian insurance companies listed at Amman Stock Exchange. Journal of Management Research, 4(2), pp. 266-289.

AlNuaimi, B. K., and Khan, M. (2019). Public-sector green procurement in the United Arab Emirates: Innovation capability and commitment to change. Journal of Cleaner Production, 233(28), pp. 482-489.

Appolloni, A., Sun, H., Jia, F., and Li, X. 2014. Green Procurement in the Private Sector: A State of the Art Review Between 1996 and 2013. Journal of Cleaner Production, 85, pp. 122-133.

Bamberg, S., Ajzen, I., and Schmidt, P. 2003. Choice of travel mode in the theory of planned behavior: The roles of past behavior, habit, and reasoned action. Basic and Applied Social Psychology, 25(3), pp. 175-187.

Blome, C., Hollos, D., and Paulraj, A. 2014. Green procurement and green supplier development: antecedents and effects on supplier performance. International Journal of Production Research, 52(1), pp. 32-49.

Carter, C. R., and Carter, J. R. 1998. Interorganizational determinants of environmental purchasing: initial evidence from the consumer products industries. Decision Sciences, 29(3), pp. 659-684. 
Carter, C. R., Kale, R., and Grimm, C. M. 2000. Environmental purchasing and firm performance: an empirical investigation. Transportation Research Part E: Logistics and Transportation Review, 36(3), pp. 219-228.

Chan, R. Y., He, H., Chan, H. K., and Wang, W. Y. 2012. Environmental orientation and corporate performance: The mediation mechanism of green supply chain management and moderating effect of competitive intensity. Industrial Marketing Management, 41(4), pp. 621-630.

Closs, D. J., Speier, C., and Meacham, N. 2011. Sustainability to support end-to-end value chains: the role of supply chain management. Journal of the Academy of Marketing Science, 39(1), pp. 101-116.

Dal Maso, L., Mazzi, F., Soscia, M., and Terzani, S. (2018). The moderating role of stakeholder management and societal characteristics in the relationship between corporate environmental and financial performance. Journal of Environmental Management, 218, pp. 322-332.

Deephouse, D. L., and Heugens, P. P. 2009. Linking social issues to organizational impact: The role of infomediaries and the infomediary process. Journal of Business Ethics, 86(4), pp. 541-553.

Esfahbodi, A., Zhang, Y., and Watson, G. 2016. Sustainable supply chain management in emerging economies: Trade-offs between environmental and cost performance. International Journal of Production Economics, 181, pp. 350-366.

Fornell, C., and Larcker, D. F. 1981. Evaluating structural equation models with unobservable variables and measurement error. Journal of Marketing Research, 18(1), pp. 39-50.

Ghosh, M. 2019. Determinants of green procurement implementation and its impact on firm performance. Journal of Manufacturing Technology Management, 30(2), pp. 462-482.

Gimenez, C., and Tachizawa, E. M. 2012. Extending sustainability to suppliers: a systematic literature review. Supply Chain Management: An International Journal, 17(5), pp. 531-543.

Green Jr, K. W., Zelbst, P. J., Meacham, J., and Bhadauria, V. S. 2012. Green supply chain management practices: impact on performance. Supply Chain Management: An International Journal, 17(3), pp. 290-305.

Gualandris, J., and Kalchschmidt, M. 2014. Customer pressure and innovativeness: Their role in sustainable supply chain management. Journal of Purchasing and Supply Management, 20(2), pp. 92-103.

Guenther, E., Scheibe, L., and Greschner Farkavcová, V. 2010. "The Hurdles Analysis” as an instrument for improving sustainable stewardship. Management Research Review, 33(4), pp. 340-356.

Güngör, P. 2011. The relationship between reward management system and employee performance with the mediating role of motivation: A quantitative study on global banks. Procedia-Social and Behavioral Sciences, 24, pp. 1510-1520. 
Hair, J. F., Ringle, C. M., and Sarstedt, M. 2011. PLS-SEM: Indeed a silver bullet. Journal of Marketing Theory and Practice, 19(2), pp. 139-152.

Heizer, J., Render, B., Munson, C., and Sachan, A. 2017. Operations Management: Sustainability and Supply Chain Management, 12/e. Pearson Education.

Henseler, J., Ringle, C. \& Sinkovics, R. (2009). “The use of partial least squares path modeling in international marketing". New Challenges to International Marketing. Vol. 20, pp. 277-320.

Hirigoyen, G., and Poulain-Rehm, T. 2015. Relationships between Corporate Social Responsibility and Financial Performance: What is the Causality?. Journal of Business Management, 4(1), pp. 18-43.

Hoejmose, S., Brammer, S., and Millington, A. 2012. "Green" supply chain management: The role of trust and top management in B2B and B2C markets. Industrial Marketing Management, 41(4), pp. 609-620.

Homburg, C., and Pflesser, C. 2000. A multiple-layer model of market-oriented organizational culture: Measurement issues and performance outcomes. Journal of Marketing Research, 37(4), pp. 449-462.

Hsu, C. W., Kuo, T. C., Chen, S. H., and Hu, A. H. 2013. Using DEMATEL to develop a carbon management model of supplier selection in green supply chain management. Journal of Cleaner Production, 56, pp. 164-172.

Huo, B. 2012. The impact of supply chain integration on company performance: an organizational capability perspective. Supply Chain Management: An International Journal, 17(6), pp. 596-610.

Huo, B., Qi, Y., Wang, Z., and Zhao, X. 2014. The impact of supply chain integration on firm performance: The moderating role of competitive strategy. Supply Chain Management: An International Journal, 19(4), pp. 369-384.

Karna, A., and Heiskanen, E. 1998. The challenge of 'product chain'thinking for product development and design - the example of electrical and electronic products. Journal of Sustainable Product Design, 4(1), pp. 26-36.

Klassen, R. D., and Vachon, S. 2003. Collaboration and evaluation in the supply chain: The impact on plant-level environmental investment. Production and Operations Management, 12(3), pp. 336-352.

Large, R. O., and Thomsen, C. G. 2011. Drivers of green supply management performance: Evidence from Germany. Journal of Purchasing and Supply Management, 17(3), pp. 176-184.

Lee, S. M., Tae Kim, S., and Choi, D. 2012. Green supply chain management and organizational performance. Industrial Management \& Data Systems, 112(8), pp. $1148-1180$.

Li, S., Ragu-Nathan, B., Ragu-Nathan, T. S., and Rao, S. S. 2006. The impact of supply chain management practices on competitive advantage and organizational performance. Omega, 34(2), pp. 107-124. 
Linton, J. D., Klassen, R., and Jayaraman, V. 2007. Sustainable supply chains: An introduction. Journal of Operations Management, 25(6), pp. 1075-1082.

Mani, V., Gunasekaran, A., and Delgado, C. (2018). Enhancing supply chain performance through supplier social sustainability: An emerging economy perspective. International Journal of Production Economics, 195, pp. 259-272.

Medarevic, S. 2012. Environmental corporate social responsibility and the carbon economy: A case for CSR, the triple bottom line and obliquity. Enterprise Governance eJournal, 1(1), pp. 1-8.

Min, H., and Galle, W. P. 2001. Green purchasing practices of US firms. International Journal of Operations \& Production Management, 21(9), pp. 1222-1238.

Mitra, S., and Datta, P. P. 2014. Adoption of green supply chain management practices and their impact on performance: an exploratory study of Indian manufacturing firms. International Journal of Production Research, 52(7), pp. 2085-2107.

Mohanty, R. P., and Prakash, A. 2014. Green supply chain management practices in India: an empirical study. Production Planning \& Control, 25(16), pp. 1322-1337.

Mokhtar, A. R. M., Genovese, A., Brint, A., and Kumar, N. 2019. Improving reverse supply chain performance: The role of supply chain leadership and governance mechanisms. Journal of Cleaner Production, 216, pp. 42-55.

Olaru, M., Dinu, V., Keppler, T., Mocan , B. and Mateiu, A., 2015. Study on the open innovation practices in Romanian SMEs. Amfiteatru Economic, 17(Special Issue nr. 9), pp.1129-1141.

Perera, C. R., and Hewege, C. 2016. Elderly consumers' sensitivity to corporate social performance. Social Responsibility Journal, 12(4), pp. 786-805.

Preuss, L. 2005. Rhetoric and reality of corporate greening: a view from the supply chain management function. Business Strategy and the Environment, 14(2), pp. 123-139.

Psomas, E., Kafetzopoulos, D., and Gotzamani, K. 2018. Determinants of company innovation and market performance. The TQM Journal, 30(1), pp. 54-73.

Rai, A., Patnayakuni, R., and Seth, N. 2006. Firm performance impacts of digitally enabled supply chain integration capabilities. MIS Quarterly, 30(2), pp. 225-246.

Rizwan, M., Ahmad, M., and Haq, M. 2014. Effect of brand trust and customer satisfaction on brand loyalty in Bahawalpur. Journal of Sociological Research, 5(1), pp. 306-326.

Safavi, H. P., and Bouzari, M. 2019. The association of psychological capital, career adaptability and career competency among hotel frontline employees. Tourism Management Perspectives, 30, pp. 65-74.

Sarkis, J., Zhu, Q., and Lai, K. H. 2011. An organizational theoretic review of green supply chain management literature. International Journal of Production Economics, 130(1), pp. 1-15.

Seman, N. A. A., Zakuan, N., Rashid, U. K., Nasuredin, J., and Ahmad, N. (2018). The Level of Adoption of Green Supply Chain Management and Green Innovation in 
Malaysian Manufacturing Industries. International Journal of Research,5(20), pp. 1556-1572.

Seuring, S., and Müller, M. 2008. From a literature review to a conceptual framework for sustainable supply chain management. Journal of Cleaner Production, 16(15), pp. $1699-1710$

Singhal, V., Flynn, B. B., Ward, P. T., Roth, A. V., and Gaur, V. 2008. Empirical elephants - Why multiple methods are essential to quality research in operations and supply chain management. Journal of Operations Management, 26(3), pp. 337-348

Soana, M. G. 2011. The relationship between corporate social performance and corporate financial performance in the banking sector. Journal of Business Ethics, 104(1), 133-148.

Solovida, G. T., and Latan, H. 2017. Linking environmental strategy to environmental performance: Mediation role of environmental management accounting. Sustainability Accounting, Management and Policy Journal, 8(5), pp. 595-619.

Treacy, M., and Wiersema, F. 1993. Customer intimacy and other value disciplines. Harvard Business Review, 71(1), pp. 84-93.

Wang, H., Tong, L., Takeuchi, R., and George, G. 2016. Corporate social responsibility: An overview and new research directions: Thematic issue on corporate social responsibility. Academy of Management Journal, 59(2), pp. 534-544.

Yook, K. H., Choi, J. H., and Suresh, N. C. 2018. Linking green purchasing capabilities to environmental and economic performance: The moderating role of firm size. Journal of Purchasing and Supply Management, 24(4), pp. 326-337.

Zailani, S., Jeyaraman, K., Vengadasan, G., and Premkumar, R. 2012. Sustainable supply chain management (SSCM) in Malaysia: A survey. International Journal of Production Economics, 140(1), pp. 330-340.

Zhu, Q., and Sarkis, J. (2004). Relationships between operational practices and performance among early adopters of green supply chain management practices in Chinese manufacturing enterprises. Journal of Operations Management, 22(3), pp. 265-289.

Zhu, Q., Sarkis, J., and Geng, Y. (2005). Green supply chain management in China: pressures, practices and performance. International Journal of Operations \& Production Management, 25(5), pp. 449-468.

Zsidisin, G. A., and Siferd, S. P. (2001). Environmental purchasing: a framework for theory development. European Journal of Purchasing \& Supply Management, 7(1), pp. 61-73. 